\title{
Disparities in fruit and vegetable supply: a potential health concern in the greater Québec City area
}

\author{
Nathalie Pouliot and Anne-Marie Hamelin* \\ Department of Food Sciences and Nutrition, Université Laval, Québec City, Québec, Canada, GIV OA6
}

Submitted 4 June 2008: Accepted 21 January 2009: First published online 6 April 2009

\begin{abstract}
Objective: The present study explores the spatial distribution and in-store availability of fresh fruits and vegetables from a socio-environmental perspective in terms of the type of food store, level of deprivation and the setting (urban/rural) where the food outlets are located.

Design: Seven types of fresh fruit and vegetable stores (FVS) were identified then visited in six districts (urban setting) and seven communities (rural setting). The quantity and diversity of fresh fruits and vegetables (F\&V) were also assessed.

Setting: Québec City, Canada.

Results: The FVS spatial distribution showed differences between the two settings, with accessibility to supermarkets being more limited in rural settings. The quantity and diversity of fresh F\&V in-store availability were associated with the type of FVS, but not with setting or its level of deprivation. Greengrocers and supermarkets offered a greater quantity and diversity of fresh F\&V than the other FVS. Conclusions: The results suggest that inequalities in physical access to fresh F\&V across the region could have an impact on public health planning considering that supermarkets, which are one of the excellent sources of $F \& V$, are less prevalent in rural settings.
\end{abstract}

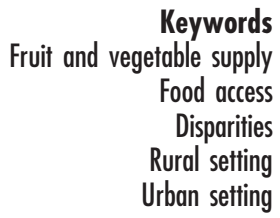

The relationship between diet and health is now fully recognized $^{(1)}$; there is strong evidence for health benefits associated with the consumption of fruits and vegetables $(\mathrm{F} \& \mathrm{~V})$. The role of a supportive environment, i.e. one that promotes making the healthiest choice into the easiest choice at the physical, economic, sociocultural or political level, was highlighted at the Ottawa Conference for Health Promotion in $1986^{(2,3)}$. The evidence base on the role of the food environment in the food-health relationship is also growing ${ }^{(4,5)}$. The food environment can be referred to as a 'set of conditions in which one person (or a group of persons) has access to, chooses, prepares and eats foods ${ }^{(6)}$. As Raine noted: 'individual determinants are necessary, but not sufficient, to explain eating behavior' $^{(5)}$. Food availability and food access, as conditions for food security, should not be overridden ${ }^{(7-11)}$. Food availability is understood as the level of supply in the food market, and food accessibility as the physical and economic ability to access the food supply ${ }^{(12)}$.

Studies that focus on the physical access to food in American urban settings, and on clarifying the extent of social disparities, point to a consistent picture ${ }^{(13)}$. Supermarkets are more prevalent in wealthier neighbourhoods than in poorer ones, and this unequal spatial distribution is also associated with the racial make-up of communities $^{(14-19)}$. Some findings also show that people living in high-income areas or those characterized by better physical access to a supermarket eat more F\&V or have significantly lower odds of obesity and overweight than those living in conditions of deprivation ${ }^{(20-22)}$. Outside the USA, studies of food access draw more on the socioeconomic status of the area than on wealth and racial composition when assessing deprivation. In Australia and the UK, studies show either no or small differences in the spatialization of food purchasing infrastructure and of food purchasing behaviour while considering the varying socio-economic factors across the target settings ${ }^{(23-26)}$.

In Canada, a few studies have found that unequal distribution of food stores has negatively impacted lowincome neighbourhoods ${ }^{(27,28)}$, while others conclude that urban households have generally good food access ${ }^{(29,30)}$. A recent research in Montréal found that $40 \%$ of the population studied had to walk more than $500 \mathrm{~m}$ to reach a source of $\mathrm{F} \& \mathrm{~V}$, without regard to the district's socioeconomic levels for which no significant relationship was found $^{(31)}$. Generalizations are difficult to make due to the varying landscape and culture observed within and across provinces and territories. Even so, the link between food access and deprivation still needs to be clarified. In rural settings, however, studies have argued that supplying food might be more difficult with regard to the travel distance and its quality and freshness ${ }^{(32-34)}$. 
To our knowledge, food access has yet to be explored in rural Québec and merits closer examination since roughly $20 \%$ of the total Québec population lives in a rural setting.

In order to fill this gap, the present study explores fresh F\&V supplies by considering the setting and its level of deprivation. The main questions being addressed are:

1. Is there a difference in the spatial distribution of food stores found in rural and urban settings, the intraurban setting and the intra-rural setting?

2. Is there a relationship between fresh $F \& V$ in-store availability, the type of food store, the specific setting and its level of deprivation?

\section{Methods}

\section{Sample}

Household food security and social inequalities in the greater Québec City area are already under investigation. Field work was thus conducted in the same area to benefit from an increasing pool of relevant data that could provided us with a basis for analysis ${ }^{(35-38)}$. Urban and rural settings were differentiated by their population: the cities with more than 10000 inhabitants being defined as 'urban' and those with less as 'rural'(39). In addition, the influence exerted by the metropolitan area, dubbed 'metropolitan areas' and 'census agglomeration-influenced zones', was also taken into account to identify rural areas $^{(40)}$. Data were collected in a sample of six contiguous urban districts of the subdivision La Cité and of seven rural communities in the regional county municipalities (RCM) of Portneuf, Charlevoix and of St-Anne-deBeaupré.* The subdivision districts and communities were chosen because of their contrasting socio-economic characteristics as assessed using the Material and Social Deprivation Index. This index combines three material deprivation parameters (education level; activity rate; mean income) and three social deprivation parameters (proportion of separated, divorced or widowed persons; proportion of single parents; proportion of persons living alone) at the dissemination area scale, creating a ninecategory typology of deprivation ${ }^{(41)}$.

\section{Data collection procedure}

Food stores census

Research (e.g. references 8, 42 and 43) and one study outlining a typology ${ }^{(44)}$ show that food may be obtained from different sources. In Québec in 2006, $71 \%$ of total food demand was met by the food retail sector against $29 \%$ by the food service industry ${ }^{(45)}$. As we focused on the most current way of acquiring fresh $\mathrm{F} \& \mathrm{~V}$, the food

* One can note that the term 'community' is employed in a general sense in this text and refers to city, village, community and parish alike; all places of the rural setting.
Table 1 Definition of the types of fresh fruit and vegetable store (FVS) under study

\begin{tabular}{|c|c|}
\hline FVS type & Definition* \\
\hline $\begin{array}{l}\text { Conveni } \\
\text { store }\end{array}$ & $\begin{array}{l}\text { Establishment where food and other basic } \\
\text { consumption articles are sold and where } \\
\text { opening is permitted outside normal business } \\
\text { hours and days of operation. Other services } \\
\text { are also on offer in order to generate traffic }\end{array}$ \\
\hline Grocery store & $\begin{array}{l}\text { Establishment where the average surface area } \\
\text { is less than } 8000 \mathrm{ft}^{2} \text { and is designed to } \\
\text { accommodate basic food needs for the } \\
\text { neighbourhood }\end{array}$ \\
\hline Supermarket & $\begin{array}{l}\text { here the average surface area } \\
\text { en } 8000 \text { and } 30000 \mathrm{ft}^{2}\end{array}$ \\
\hline Superstore & $\begin{array}{l}\text { Establishment where the average surface area } \\
\text { ranges between } 30000 \text { and } 100000 \mathrm{ft}^{2} \\
\text { offering food in self-service aisles and } \\
\text { competitive low prices. A large amount of } \\
\text { food supplies, general products and } \\
\text { complementary services are available }\end{array}$ \\
\hline Greengrocer & $\begin{array}{l}\text { Establishment designed to sell fruits and } \\
\text { vegetables }\end{array}$ \\
\hline Specialty storet & $\begin{array}{l}\text { Establishment designed to sell specific food } \\
\text { supplies }\end{array}$ \\
\hline
\end{tabular}

*The definitions are extracted and translated from Marquis and Simard ${ }^{(66)}$. tIn the present study, specialty stores were further divided into 'natural food stores' and 'delicatessen'.

stores census was limited to the retail sector and precisely to those stores that are likely to carry them. Table 1 provides a definition for each type of fresh fruit and vegetable store (FVS) identified in the present study.

To create a list of FVS, various databases were utilized, including the software Business 411 (2005; Tame Inc., Flintstone, GA, USA), accessible with the agreement of the Centre for Research in Regional Planning and Development (Laval University), and a registry from the Québec Ministry of Agriculture (2005). During data collection, the local telephone directory allowed us to verify addresses of stores that could not readily be located. Local visits also helped to complete and validate the list.

\section{In-store availability}

With reference to current Canadian studies, two main indicators - quantity and diversity - were defined to measure $F \& V$ in-store availability ${ }^{(28,31,46,47)}$. First, a proxy measure of $\mathrm{F} \& \mathrm{~V}$ quantity was developed, by estimating the length and width of stalls to calculate total shelfsurface $\left(\mathrm{ft}^{2}\right)$. Second, to measure diversity, the different varieties of $\mathrm{F} \& \mathrm{~V}$ available were counted, with variety being understood here as belonging to a similar taxonomic group. For example, all types of apples (e.g. McIntosh, Delicious, Granny Smith) were considered as belonging to one variety of fruit: the apple. A predefined list of the varieties of fruits (thirty-eight) and vegetables (thirty-seven) was used as a base by the observer.

\section{Processes}

Data were collected in September 2006, when F\&V supply is bountiful. In order to minimize possible bias, only one 
observer (N.P.) visited the FVS ${ }^{(47)}$. The process of observation, described on the answer sheet (prepared and pretested in order to facilitate data collection), was carefully applied at each food store included in the study. Information was gathered by using a digital recorder. A second visit was made to a random sample (10\%) of stores located in the La Cité subdivision to assess the reliability of the measure of F\&V quantity and diversity ${ }^{(48)}$.

\section{Analyses}

Statistical analyses were performed with the SPSS software package version 11.5 for Windows (SPSS Inc., Chicago, IL, USA), with a significance level of $P<0 \cdot 05$. For each community and district, the FVS spatial distribution (frequency of stores per 10000 population and per $\mathrm{km}^{2}$ ) was estimated using population and territory data from Statistics Canada's 2001 census results in order to compare their frequency rates ${ }^{(42,49,50)}$. One-way ANOVA were then performed to evaluate the significance of differences in distribution between rural and urban settings. Due to sample sizes, no statistical analyses were performed at the intra-urban and intra-rural levels. General linear model (GLM) univariate procedures were employed to identify any interaction between the quantity and the diversity (dependent variables) and the type of FVS, the setting and the Material and Social Deprivation Index (as fixed factor). Dunnet T3 post hoc procedures were used when a significant association was perceived ${ }^{(51)}$. Moreover, test-retest reliability was confirmed with paired-sample $t$ tests.

The FVS spatial distribution was mapped using a specific symbol for each type of store. The F\&V in-store availability (quantity and diversity) was also illustrated with four tones of colour ranging from white (nil), light grey (moderate), dark grey (good) to black (excellent). These categories were defined according to the natural clusters: no variety and no shelf-surface (nil); one to nineteen varieties and $1-99 \mathrm{ft}^{2}$ of shelf-surface (moderate); twenty to thirty-nine varieties and exactly $100 \mathrm{ft}^{2}$ of shelf-surface (good); and forty or more varieties and $101 \mathrm{ft}^{2}$ or more shelf-surface (excellent). All maps were created using Mapinfo version 8.5 (Pitney Bowes MapInfo, Troy, NY, USA).

\section{Results}

\section{Characteristics of the studied area}

The area under study $\left(2230 \cdot 1 \mathrm{~km}^{2}\right)$ is home to a population of 84874 inhabitants. The majority lives in an urban setting (62110 inhabitants in an area of $11 \cdot 8 \mathrm{~km}^{2} v .22764$ inhabitants in a rural area of $2218 \cdot 3 \mathrm{~km}^{2}$ ). There are significant differences in the socio-economic and demographic characteristics between urban and rural settings. Globally, the rural setting is more deprived materially than the urban setting, as already observed for the same region by DeKoninck et al. ${ }^{(36)}$.

\section{Frequency and spatial distribution of fresh fruit and vegetable stores}

A total of 144 FVS were visited. Among these, 74\% were located in the urban subdivision. In all stores found in the studied area, half were convenience stores (51\%) and few of them were superstores and greengrocers (11\%). Within the urban setting, one district (Vieux-Québec/Cap-Blanc) was served mostly by convenience stores and had no supermarkets, superstores or greengrocers. Also, two districts (St-Jean-Baptiste and St-Sauveur) were relatively underserved by supermarkets; otherwise they enjoyed many more grocery stores than the other districts. The number of specialty stores was similar in all districts. Within the rural setting, three communities (Les Éboulements, St-Hilarion and Rivière-à-Pierre) relied only on convenience or grocery stores and one (Ste-Christined'Auvergne) had no FVS at all. At least one community visited per RCM was home to a supermarket (St-Raymond, Baie St-Paul and Ste-Anne-de-Beaupré), but only one of the communities had a greengrocer (St-Raymond).

Table 2 shows the mean distribution of each type of FVS by setting. With regard to the FVS/10 000 population measure, one-way ANOVA analyses indicated no differences, except for a higher number of delicatessen and natural food stores per 10000 population $(P=0 \cdot 018$ and $P=0 \cdot 033$, respectively) in the urban setting. This implies that city dwellers have better access to more specialty stores than rural inhabitants. Likewise, an examination of the distribution of $\mathrm{FVS} / \mathrm{km}^{2}$ showed that with the exception of greengrocers and superstores, there were

Table 2 Mean distribution of fresh fruit and vegetable stores by type of setting: greater Québec City area, Canada, September 2006

\begin{tabular}{|c|c|c|c|c|c|c|c|}
\hline Setting/variable & Convenience store & Grocery store & Supermarket & Superstore & Greengrocer & Natural food store & Delicatessen \\
\hline \multicolumn{8}{|l|}{ Urban } \\
\hline$n$ & 53 & 24 & 8 & 0 & 2 & 4 & 15 \\
\hline$\%$ & $72 \cdot 6$ & $75 \cdot 0$ & $61 \cdot 5$ & - & $66 \cdot 7$ & $80 \cdot 0$ & $88 \cdot 2$ \\
\hline No./10 000 population & $9 \cdot 50$ & $4 \cdot 00$ & $1 \cdot 17$ & 0.00 & 0.33 & 0.50 & $2 \cdot 50$ \\
\hline No. $/ \mathrm{km}^{2}$ & $4 \cdot 58$ & $2 \cdot 01$ & $0 \cdot 71$ & 0.00 & $0 \cdot 18$ & 0.39 & $1 \cdot 29$ \\
\hline \multicolumn{8}{|l|}{ Rural } \\
\hline$n$ & 20 & 8 & 5 & 1 & 1 & 1 & 2 \\
\hline$\%$ & $27 \cdot 4$ & $25 \cdot 0$ & $38 \cdot 5$ & $100 \cdot 0$ & $33 \cdot 3$ & $20 \cdot 0$ & $11 \cdot 8$ \\
\hline No./10 000 population & $8 \cdot 84$ & $6 \cdot 65$ & $1 \cdot 19$ & 0.51 & $0 \cdot 14$ & $0.00^{*}$ & $0.71^{*}$ \\
\hline No. $/ \mathrm{km}^{2}$ & $0 \cdot 03^{*}$ & $7 \cdot 14 \times 10^{-3 *}$ & $3 \cdot 16 \times 10^{-3 *}$ & $2.22 \times 10^{-3}$ & $2 \cdot 14 \times 10^{-4}$ & $1.43 \times 10^{-3 *}$ & $3.14 \times 10^{-3 *}$ \\
\hline
\end{tabular}

*Significant difference compared with the urban setting $(P<0.05)$. 
relatively more FVS in the urban setting (convenience store $P=0 \cdot 000$; grocery store $P=0 \cdot 003$; supermarket $P=0 \cdot 001$; delicatessen $P=0 \cdot 000$; natural food store $P=0 \cdot 037$ ).

\section{In-store availability}

Thirty-four per cent of all food stores surveyed did not carry $\mathrm{F} \& \mathrm{~V}$; almost half of them (48\%) being convenience stores (data not shown). The total shelf-surface area means for $\mathrm{F} \& \mathrm{~V}$ were much higher in supermarkets and greengrocers $\left(>200 \mathrm{ft}^{2}\right)$ than in any other type of FVS $\left(<100 \mathrm{ft}^{2}\right.$; Table 3$)$. The same observation can be made regarding the total variety means, where supermarkets and greengrocers carried more than fifty varieties while other FVS had less than twenty (Table 4).

The results of the GLM univariate procedures are presented in Table 5. No significant association was observed in the interaction model. When looking at the separated effects of the fixed factors on the indicators of quantity and diversity, the type of FVS was the only factor that was significantly associated with shelf-surface area and number of varieties. The total shelf-surface area means and the total variety means were higher in greengrocers and supermarkets than in the other FVS types regardless of the setting or level of deprivation. This suggests that the FVS type is a good predictor of the F\&V supply.

Finally, the paired-sample $t$ test demonstrated no difference for shelf-surface area and number of varieties between the collected data and the data from the $10 \%$ random sample.

\section{Mapping}

Among the FVS located in the six districts comprising the urban setting (Fig. 1), those rated excellent for their in-store availability of F\&V were distributed evenly across

Table 3 Fresh fruit and vegetable mean total shelf-surface area $\left(\mathrm{ft}^{2}\right)$ per type of fresh fruit and vegetable store (FVS) in urban and rural settings: greater Québec City area, Canada, September 2006

\begin{tabular}{|c|c|c|c|c|c|c|c|c|}
\hline \multirow[b]{2}{*}{ FVS type } & \multicolumn{4}{|c|}{ Urban } & \multicolumn{4}{|c|}{ Rural } \\
\hline & Mean & Minimum & Maximum & $n$ & Mean & Minimum & Maximum & $n$ \\
\hline Convenience store & $2 \cdot 2$ & 0.0 & $26 \cdot 7$ & 53 & $3 \cdot 6$ & $0 \cdot 0$ & $33 \cdot 2$ & 20 \\
\hline Grocery store & $49 \cdot 8$ & 0.0 & $343 \cdot 2$ & 24 & $21 \cdot 7$ & 0.0 & $61 \cdot 8$ & 8 \\
\hline Supermarket & 328.6 & $196 \cdot 1$ & $505 \cdot 4$ & 8 & $463 \cdot 7$ & $342 \cdot 8$ & $756 \cdot 0$ & 6 \\
\hline Greengrocer & $492 \cdot 1$ & $439 \cdot 3$ & $544 \cdot 9$ & 2 & $208 \cdot 7$ & $208 \cdot 7$ & $208 \cdot 7$ & 1 \\
\hline Natural food store & $74 \cdot 1$ & 0.0 & $254 \cdot 3$ & 4 & $13 \cdot 0$ & $13 \cdot 0$ & $13 \cdot 0$ & 1 \\
\hline Delicatessen & $24 \cdot 7$ & $0 \cdot 0$ & $124 \cdot 9$ & 15 & $0 \cdot 1$ & 0.0 & 0.3 & 2 \\
\hline All FVS types & $52 \cdot 8$ & 0.0 & $544 \cdot 9$ & 106 & $85 \cdot 5$ & 0.0 & $756 \cdot 0$ & 38 \\
\hline
\end{tabular}

$1 \mathrm{ft}^{2} \approx 0 \cdot 1 \mathrm{~m}^{2}$.

Table 4 Fresh fruit and vegetable mean total variety (counted number of varieties) per type of fresh fruit and vegetable store (FVS) in urban and rural settings: greater Québec City area, Canada, September 2006

\begin{tabular}{|c|c|c|c|c|c|c|c|c|}
\hline \multirow[b]{2}{*}{ FVS type } & \multicolumn{4}{|c|}{ Urban } & \multicolumn{4}{|c|}{ Rural } \\
\hline & Mean & Minimum & Maximum & $n$ & Mean & Minimum & Maximum & $n$ \\
\hline Convenience store & $2 \cdot 2$ & 0 & 16 & 53 & $2 \cdot 9$ & 0 & 15 & 20 \\
\hline Grocery store & $13 \cdot 0$ & 0 & 52 & 24 & $10 \cdot 1$ & 1 & 19 & 8 \\
\hline Supermarket & $52 \cdot 8$ & 43 & 58 & 8 & $51 \cdot 8$ & 42 & 60 & 6 \\
\hline Greengrocer & $62 \cdot 0$ & 60 & 64 & 2 & $48 \cdot 0$ & 48 & 48 & 1 \\
\hline Natural food store & $19 \cdot 3$ & 0 & 60 & 4 & $18 \cdot 0$ & 18 & 18 & 1 \\
\hline Delicatessen & $29 \cdot 4$ & 0 & 44 & 15 & $0 \cdot 0$ & 0 & 0 & 2 \\
\hline All FVS types & $11 \cdot 3$ & 0 & 64 & 106 & $13 \cdot 6$ & 0 & 60 & 38 \\
\hline
\end{tabular}

Table 5 Variables influencing fresh fruit and vegetable in-store availability: greater Québec City area, Canada, September 2006

\begin{tabular}{|c|c|c|c|c|c|c|c|}
\hline & \multirow[b]{2}{*}{ Model variable } & \multicolumn{2}{|c|}{ Vegetables } & \multicolumn{2}{|c|}{ Fruits } & \multicolumn{2}{|c|}{ Fruits and vegetables } \\
\hline & & $F$ & $P$ & $F$ & $P$ & $F$ & $P$ \\
\hline \multirow{4}{*}{ Shelf-surface area } & Type of FVS $\times$ setting $\times$ level of deprivation & $0 \cdot 2$ & 0.96 & 0.2 & 0.95 & $0 \cdot 2$ & 0.96 \\
\hline & Type of FVS & $101 \cdot 8$ & 0.00 & $45 \cdot 7$ & 0.00 & $80 \cdot 8$ & 0.00 \\
\hline & Setting & 0.5 & 0.47 & $0 \cdot 0$ & $0 \cdot 84$ & $0 \cdot 3$ & $0 \cdot 61$ \\
\hline & Level of deprivation & $0 \cdot 8$ & $0 \cdot 61$ & 0.3 & 0.94 & 0.5 & $0 \cdot 81$ \\
\hline \multirow{4}{*}{ Variety } & Type of FVS $\times$ setting $\times$ level of deprivation & $1 \cdot 0$ & $0 \cdot 40$ & $0 \cdot 3$ & $0 \cdot 76$ & $0 \cdot 8$ & 0.57 \\
\hline & Type of FVS & $46 \cdot 1$ & 0.00 & $51 \cdot 0$ & 0.00 & $50 \cdot 9$ & 0.00 \\
\hline & Setting & $0 \cdot 3$ & 0.58 & $0 \cdot 6$ & 0.46 & $0 \cdot 4$ & 0.52 \\
\hline & Level of deprivation & $1 \cdot 2$ & 0.33 & $1 \cdot 4$ & 0.23 & $1 \cdot 2$ & $0 \cdot 30$ \\
\hline
\end{tabular}

FVS, fruit and vegetable store.

All results shown before post hoc procedure. 


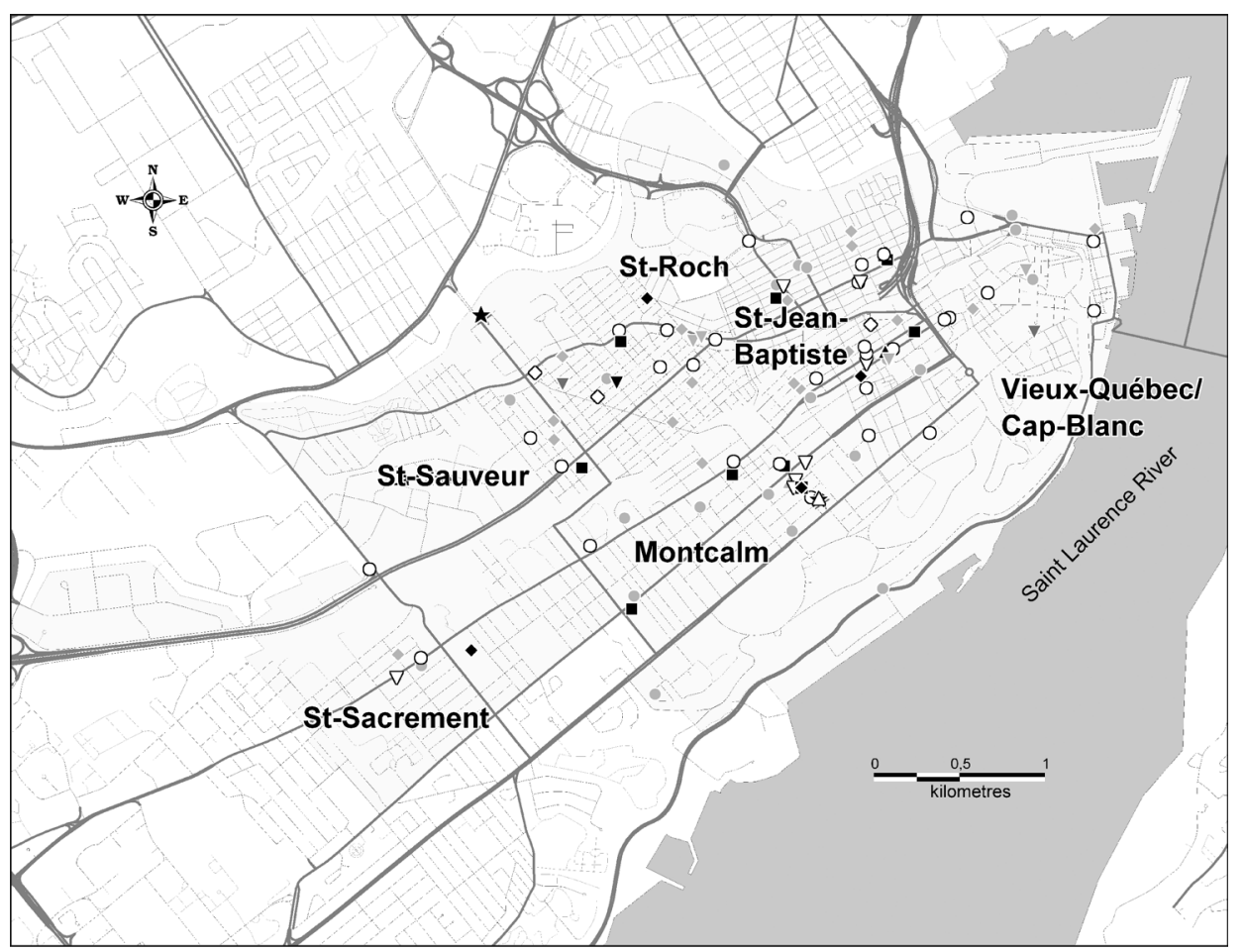

Fig. 1 Map of the urban setting (La Cité subdivision) showing location of fruit and vegetable store types $(\bigcirc$, convenience store; $\diamond$, grocery store; $\square$, supermarket, $t^{2}$, greengrocer; $\Delta$, natural food store; $\nabla$, delicatessen) and their in-store availability of fresh fruits and vegetables ( $\square$, nil; $\square$, moderate; $\square$, good; $\square$, excellent): greater Québec City area, Canada, September 2006

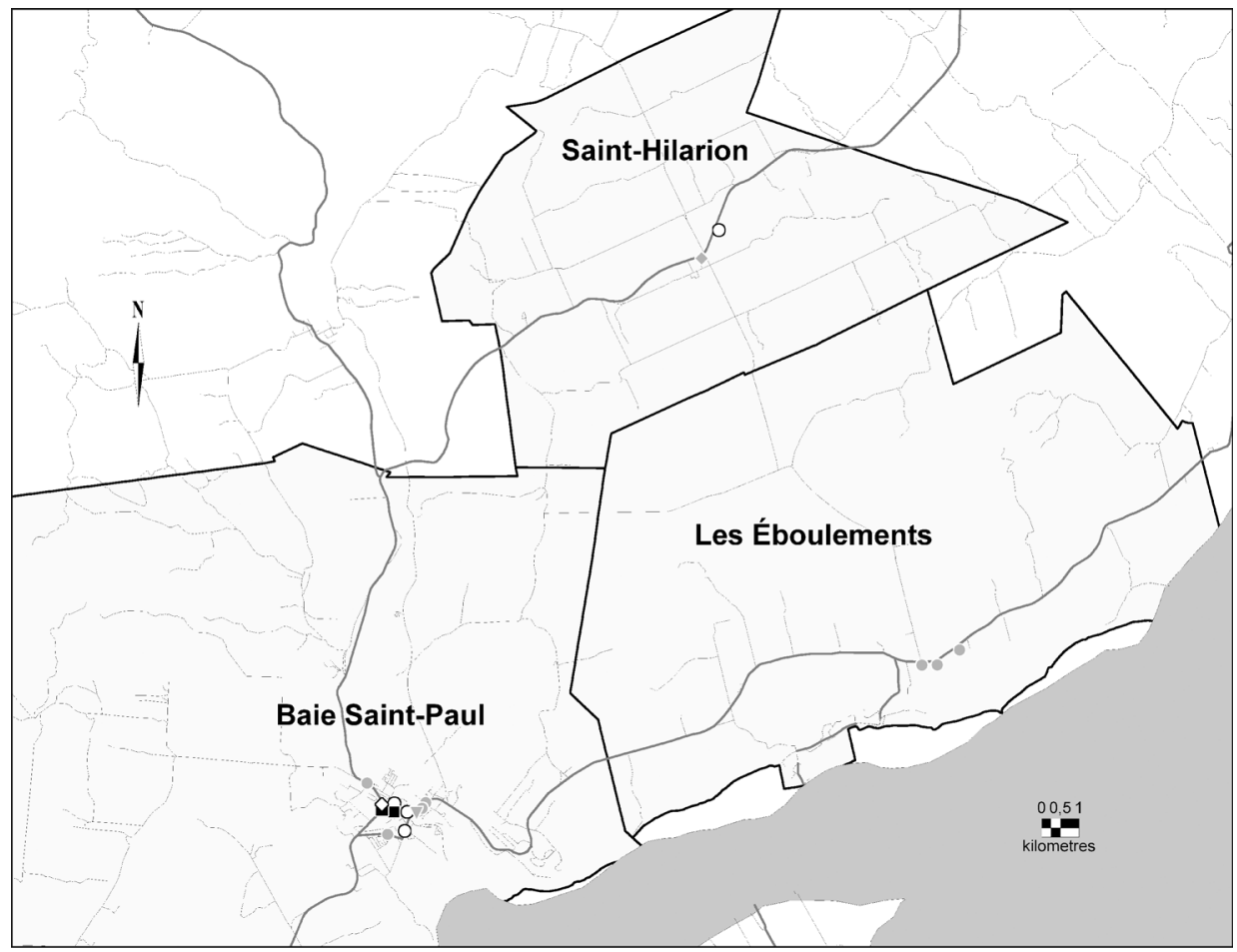

Fig. 2 Map of one regional county municipality of the rural setting (Charlevoix) showing location of fruit and vegetable store types $(\bigcirc$, convenience store; $\diamond$, grocery store; $\square$, supermarket, it, greengrocer; $\Delta$, natural food store; $\nabla$, delicatessen) and their in-store availability of fresh fruits and vegetables ( $\square$, nil; $\square$, moderate; $\square$, good; $\mathbf{\square}$, excellent): greater Québec City area, Canada, September 2006 
the subdivision, with the exception of the St-Sacrement and Vieux-Québec/Cap-Blanc districts. However, people living in St-Sacrement could access FVS located just outside the study area, thus addressing part of the issue of food access. Vieux-Québec/Cap-Blanc, situated by the St-Lawrence River, clearly provides limited access to F\&V. The three rural settings revealed a very different picture, which corroborates the results obtained from the oneway ANOVA. Figure 2 presents the map of the RCM of Charlevoix (observations for the other two RCM are identical, therefore no map is included). It illustrates that F\&V supply in two of the three rural communities is nil or moderate (Les Éboulements and St-Hilarion), while one community's supply is excellent (Baie St-Paul).

\section{Discussion}

Two major findings emerge from the present study. First, differences exist between rural and urban settings in the greater Québec City area in terms of FVS spatial distribution. Second, observations made of the quantity and diversity of fresh F\&V in-store availability suggest that the type of food retailer is the best indicator to predict fresh F\&V supply. We believe the study also yields new insights into methodology and goes beyond the mere identification of the location of FVS on a map. Indeed, by qualifying F\&V variety and quantity, we have provided a better assessment of true population access to F\&V.

\section{Trends in the distribution of fresh fruit and vegetable stores}

Whether living in an urban or rural setting, people seem to have access, in the same proportion, to almost all types of FVS studied (except for specialty stores) even though their spatial distribution is less scattered in the urban setting. However, the distance to FVS is considerably higher for people in rural settings. This unequal access to F\&V, which could have an even larger impact on nonmotorized households, can lead to health disparities ${ }^{(29)}$. The present study argues that, in general, spatial access to FVS is significantly higher for those living in urban settings. Still when comparing FVS intra-urban spatial distribution, some inconsistencies appear between the districts as suggested in other Canadian studies that found disparities in food store distribution ${ }^{(27,28)}$. Therefore, the scope of future research on the intra-urban distribution of food stores in the area should be broadened to include other relevant aspects such as transportation.

The present results show that spatial distribution patterns are complex in the intra-rural setting. Rural Québec has been witnessing a steady economic and population decline ${ }^{(39)}$, which is reflected in the food supply services of some rural areas. The picture seems standard in rural settings, where some communities act as central hubs providing the main services to the periphery ${ }^{(52)}$. For example,
Baie St-Paul and St-Raymond are hubs servicing the surrounding communities like Ste-Christine-d'Auvergne. In fact, Ste-Christine-d'Auvergne residents need to drive about $30 \mathrm{~km}$ to and from the nearest food store (located in St-Raymond). Other communities like Neuville, outside the study area, could also provide them with services, but distances remain a problem, emphasizing the need to address disparities in access to food.

Outlying communities located in rural settings provide nothing but convenience or grocery stores. One can expect that these communities would have tried to improve their supply and better meet the needs of local residents. In Fig. 2, it is clear that in-store availability of fresh F\&V is poor or even non-existent (moderate and nil). Thus, these communities appear ideal places to launch a community-based nutrition programme in partnership with food stores ${ }^{(53)}$. Some authors point out as well that local stores have the capacity to provide quality services to residents ${ }^{(12,54,55)}$ and help support the local economy while respecting social and environmental values $^{(32)}$

FVS spatial distribution may vary according to type of setting and population characteristics. For example, in the Montréal metropolitan area, peripheral neighbourhoods are less dense and more motorized and presumably have fewer but larger food stores, whereas central neighbourhoods are denser and less motorized and presumably have a greater number of smaller food stores ${ }^{(29)}$. As mentioned before, the focus of the present study was only on the retail sector. Further information is thus needed to help interpret results from our study and others. Alternative or informal ways of acquiring food, such as directly from farms, public or farmers' markets, or from home gardening, were not taken into account. It would be relevant to include the relative impact of these other sources on food provisioning. Food supply differences between the two settings may be a factor in determining food access. Therefore, in a public health context, it must be made clear from the start that urban and rural settings are two distinct food environments.

\section{The type of fresh fruit and vegetable store: an indicator of availability}

The type of FVS serves as a better indicator of the availability of fresh F\&V than the setting and the level of deprivation. This finding corroborates results of studies conducted by Cummins and Macintyre in the $\mathrm{UK}^{(34)}$ and Winkler et al. in Australia ${ }^{(24)}$. This finding also aligns with the conclusion reached in Bertrand's Montréal study, arguing that poor access to the F\&V supply is not associated with population median income (a socio-economic measure of deprivation) in a given dissemination area ${ }^{(31)}$. However, a study in a New York City neighbourhood reveals some disparity in in-store availability of fresh fruit and vegetables between a poor community and an affluent community living side by side ${ }^{(56)}$. Comparisons 
are difficult to make given that the indices of deprivation used in these studies are drawn on social and economic variables that differed from ours. Furthermore, as suggested by Ball et al., the FVS spatial distribution and the nature of supply chains could be country-specific, thus reflecting differences in institutional and legal frameworks and urban planning policies ${ }^{(4)}$.

Our research shows that the variety of fresh $\mathrm{F} \& \mathrm{~V}$ available in supermarkets is superior to that in smaller food stores. This finding corroborates those of Horowitz's and Bodor's groups ${ }^{(56,57)}$. It also reaches the conclusion that convenience stores do not represent a viable source of fresh F\&V, even in rural settings. We suggest, moreover, that the significant relationship observed between the type of FVS and in-store availability could be explained in part by the increasingly oligopolistic food retail sector, which some refer to as the North American Agro-Food Complex ${ }^{(58,59)}$. Since the 1980 s, independent chains have been unable to maintain their market share ${ }^{(45,58)}$ and the food store types are being standardized ${ }^{(60)}$. These changes seem to dictate how the retail sector is evolving and the availability of products. From a population health perspective, it is necessary to ensure that the changing nature of the retail sector leads to an increase in the fresh F\&V supply and their access.

\section{Methodology issues}

The present exploratory study examined FVS spatial distribution by comparing the frequency of each type of store in relation to land area population density. Its focus on fresh $\mathrm{F} \& \mathrm{~V}$ in-store availability contributed to our understanding of the food environment.

Drawing on other Canadian studies ${ }^{(28,46,47)}$, the data collection method used in the current study was first pre-tested before the research process began. High consistency in the results confirms the reliability of the process and adds some certainty to the method. Shelf-surface area appears also as a relatively precise measure of what is available even though the actual height or depth of the shelf used to hold F\&V is not considered. It goes further than the simple 'yes or no' method used by Cummins and Macintyre $^{(34)}$ or the F\&V total surface area in food stores measure developed by Bertrand ${ }^{(28)}$. Indeed, our study allows for a precise assessment of in-store availability and, in so doing, it seeks to improve our understanding of methodological issues in research on food supply.

The relatively low number of FVS sampled in the rural setting could reflect the small sample size or rather the reality of this setting's food environment, which is characterized by less FVS. An extended study area would further enhance our understanding of FVS spatial distribution in a rural or urban setting and at the intra-rural/ intra-urban levels.

Measuring all aspects of food access in one study design represents a great challenge for researchers. Aspects to be addressed include where people shop and in which context, the convenience of opening hours, delivery services, the means of accessing stores, rates of stock turnover, the time of the year, food price and discounts, selection of food products that meet consumer preferences and the social perception of food stores. Also, creating a reliable measure of food accessibility is difficult because the conceptual construct could be better operationalized. The sociocultural acceptance of the food supply sources, or the supply itself, is also another key aspect of food access ${ }^{(60)}$, but is rarely assessed in studies.

\section{Future research: consumer perceptions and links with bealth}

According to our results, supermarkets and greengrocers represent the main sources of fresh F\&V. Knowing that these constitute a food group for which low consumption is associated with non-transmissible diseases, the limited spatial access to supermarkets in the rural setting is a source of health concern ${ }^{(1)}$. With the intention of creating supportive environments for healthy eating, the results warrant further investigation on food consumption and its determinants. Thinking about solutions to health disparities raises the importance of considering how people interact with their food environment. Both individual and environmental determinants influence food behaviours, but their relationships have yet to be clarified ${ }^{(5,61)}$. In health promotion, it is essential to consider the needs of the population and to involve them when trying to solve a problem ${ }^{(62-64)}$. According to Carey, the population should be empowered to talk with their retailers about issues that are a concern to them ${ }^{(65)}$. Being an economic sector, food retailing implies that merchants may not change or adapt their food supply unless pressure comes from consumers or a law forces them to do so. Moreover, according to a recent study carried out in the greater Québec City area, people's perception of problems and social cohesion varies between neighbourhoods and/or localities, and perceptions of place appear to be significant predictors of people's health ${ }^{(35)}$. This observation reinforces the significance of getting people to address their issues of food access and then adapt the solutions to their local reality. Their involvement could also help highlight distinctions between urban and rural settings and develop an alternative framework for public health planning in rural settings.

\section{Acknowledgements}

We are grateful for the financial support provided to the first author by the Agence de la santé et des services sociaux de la Capitale-Nationale and the Fondation de l'Universite Laval. We thank the Centre for Research in Regional Planning and Development (CRAD, Université Laval, Québec City) for their insight and expertise. We also acknowledge the contribution of the advisory 
committee members who helped us carry out this research. There are no conflicts of interest in this study. N.P., the first author, developed the study design, collected and analysed the data, and wrote the paper as part of her master's degree. A.-M.H. provided guidance and assistance all along the research and writing process.

\section{References}

1. World Health Organization/Food and Agriculture Organization of the United Nations (2003) Diet, Nutrition and the Prevention of Chronic Diseases. Joint WHO/FAO Expert Consultation. WHO Technical Report Series no. 916. Geneva: WHO.

2. Milio N (1983) Next steps in community health policy: matching rhetoric and reality. Community Health Stud 7, 185-192.

3. World Health Organization (2006) Ottawa Charter for Health Promotion. First International Conference on Health Promotion, Ottawa, 21 November 1986. http://www. who.int/healthpromotion/conferences/previous/ottawa/en/ (accessed June 2006).

4. Ball K, Timperio AF \& Crawford DA (2006) Understanding environmental influences on nutrition and physical activity behaviors: where should we look and what should we count? Int J Nutr Phys Act 3, 1-8.

5. Raine KD (2005) Determinants of healthy eating in Canada: an overview and synthesis. Can J Public Heath 96, Suppl. 3, S8-S14.

6. Ouellet S, Hamelin A-M, Auger P \& Galarneau A (2007) Les linguisticiels et la terminologie: le cas de la nutrition publique. La Banque des mots, Revue de terminologie française 74, 5-25.

7. Hamelin A-M, Habicht J-P \& Beaudry M (1999) Food insecurity: consequences for the household and broader social implications. J Nutr 129, 2 S Suppl., 525S-528S.

8. Campbell CC (1991) Food insecurity: a nutritional outcome or a predictor variable? J Nutr 121, 408-415.

9. Tarasuk V (2004) Health implications of food insecurity. In Social Determinants of Health: Canadian Perspectives, p. 187 [D Raphael, editor]. Toronto: Canadian Scholar's Press Inc.

10. Jyoti DF, Frongillo EA Jr \& Jones S (2005) Food insecurity affects school children's academic performance, weight gain, and social skills. J Nutr 135, 2831-2839.

11. Koc M \& Dahlberg KA (1999) The restructuring of food systems: trends, research, and policy issues. Agric Human Values 16, 109-116.

12. Clifford G \& David G (2004) Measuring physical access to 'healthy foods' in areas of social deprivation: a case study in Cardiff. Int J Consum Stud 28, 222-234.

13. Cummins S \& Macintyre S (2006) Food environments and obesity - neighbourhood or nation? Int J Epidemiol 35, 100-104.

14. Morland K, Wing S, Roux AD \& Poole C (2002) Neighborhood characteristics associated with the location of food stores and food service places. Am J Prev Med 22, 23-29.

15. Dalton E, Ehrlich S, Flores M, Heberlein E \& Niemeyer M (2004) Food Availability in Allegheny County. Policy and Management Paper vol. 1 issue 1. Pittsburgh, PA: The Heinz School Review.

16. Chung C \& Myers SL Jr (1999) Do the poor pay more for food? An analysis of grocery store availability and food price disparities. J Consum Aff 33, 276-296.

17. Cotterill RW \& Franklin AW (1995) The urban grocery store gap. Food Mark Policy 8, 1-79.
18. Baker EA, Schootman M, Barnidge E \& Kelly C (2006) The role of race and poverty in access to foods that enable individuals to adhere to dietary guidelines. Prev Chron Dis 3, A76.

19. Zenk SN, Schulz AJ, Israel BA, James SA, Bao S \& Wilson ML (2005) Neighborhood racial composition, neighborhood poverty and the spatial accessibility of supermarkets in metropolitan Detroit. Am J Public Health 95, 660-667.

20. Diez-Roux AV, Nieto FJ, Caufield L, Tyroler HA, Watson RL \& Szklo M (1999) Neighborhood differences in diet: the Atherosclerosis Risk in Communities (ARIC) Study. J Epidemiol Community Health 53, 55-63.

21. Rose D \& Richards R (2004) Food store access and household fruit and vegetable use among participants in the US Food Stamp Program. Public Health Nutr 7, 1081-1088.

22. Morland K, Roux AVD \& Wings S (2006) Supermarkets, other food stores, and obesity: The Atherosclerosis Risk in Communities Study. Am J Prev Med 30, 333-339.

23. Turrell G, Blakely T, Patterson C \& Oldenburg B (2004) A multilevel analysis of socioeconomic (small area) differences in household food purchasing behavior. J Epidemiol Community Health 58, 208-215.

24. Winkler E, Turrell G \& Patterson C (2006) Does living in a disadvantaged area mean fewer opportunities to purchase fresh fruit and vegetables in the area? Finding from the Brisbane Food Study. Health Place 12, 306-319.

25. Donkin AJ, Dowler EA, Stevenson SJ \& Turner SA (1999) Mapping access to food at a local level. Br Food J 101, 554-564.

26. Cummins S \& Macintyre S (1999) The location of food stores in urban areas: a case study in Glasgow. $\mathrm{Br}$ Food J 101, 545-553.

27. Latham J \& Moffat T (2007) Determinants of variation in food cost and availability in two socioeconomically contrasting neighbourhoods of Hamilton, Ontario, Canada. Health Place 13, 273-287.

28. Bertrand L, Thérien F \& Cloutier MS (2008) Measuring and mapping disparities in access to fresh fruits and vegetables in Montréal. Can J Public Health 99, 6-11.

29. Apparicio P, Cloutier M-S \& Shearmur R (2007) The case of Montréal's missing food deserts: evaluation of accessibility to food supermarkets. Int J Health Geogr 6, issue 4, 1-13.

30. Smoyer-Tomic KE, Spence JC \& Amrhein C (2006) Food deserts in the prairies? Supermarket accessibility and neighborhood need in Edmonton, Canada. Prof Geogr 58, 307-326.

31. Bertrand L (2006) Les disparités dans l'accès à des aliments santé à Montréal: une étude géomatique. Montréal: Direction de Santé Publique Montréal.

32. Burns C, Gibbon P, Boak R, Baudinette S \& Dunbar J (2004) Food cost and availability in a rural setting in Australia. Rural Remote Health 4, 311.

33. Skerratt S (1999) Food availability and choice in rural Scotland: the impact of 'place'. Br Food J 101, 537-544.

34. Cummins S \& Macintyre S (2002) A systematic study of an urban foodscape: the price and availability of food in Greater Glasgow. Urban Stud 39, 2115-2130.

35. Pampalon R, Hamel D, DeKoninck M \& Disant M-J (2007) Perception of place and health: differences between neighborhoods in the Québec City region. Soc Sci Med 65, 95-111.

36. DeKoninck $M$, Clément $M$, Hamelin AM, Pampalon R, Paquet G, Trudel MJ with the collaboration of Vézina M \& Giguère K (2006) Trois territoires, trois réalités. Éléments d'analyse comparative sur la construction des inégalités sociales de santé. Monographie. Québec: Département de médecine sociale et préventive, Université Laval, Équipe de recherche sur les inégalités sociales de santé.

37. Hamelin A-M, Beaudry M \& Habicht J-P (2002) Characterization of household food insecurity in Québec: food and feelings. Soc Sci Med 54, 119-132. 
38. Hamelin A-M, Mercier C \& Bédard A (2008) Perception of needs and responses in food security: divergence between households and stakeholders. Public Health Nutr 11, 1389-1396.

39. Martinez J, Pampalon R, Hamel D \& Raymond G (2004) Vivre dans une collectivité rurale plutôt qu'en ville fait-il vraiment une différence en matière de santé et de bienêtre. Québec: Institut national de santé publique du Québec.

40. Statistique Canada (2000) Zones d'influence des régions métropolitaines de recensement et des agglomérations de recensement (ZIM): description de la méthodologie. http:// www.statcan.ca/bsolc/francais/bsolc?catno $=92 \mathrm{~F} 0138 \mathrm{M} 2000002$ (accessed May 2006).

41. Pampalon R \& Raymond G (2003) Indice de défavorisation matérielle et sociale: son application au secteur de la santé et du bien-être. Santé, société et solidarité 1, 191-208.

42. Barbolet H, Cuddeford V, Jeffries F, Korstad H, Kurbis S, Mark S, Miewals C \& Moreland F (2005) Vancouver Food System Assessment. Vancouver: City of Vancouver's Department of Social Planning and Simon Fraser University's Centre for Sustainable Community Development.

43. Power E (2005) Individual and household food insecurity in Canada: Position of Dietitians of Canada. Can J Diet Pract Res 66, 43-46.

44. Pouliot N \& Hamelin A-M (2006) Food access sources: proposal of a typology (poster). Presented at Journées annuelles de santé publique, Montréal, 23-27 October 2006.

45. Brouillette H (2005) Profil et performance de la restauration québécoise. Québec: Association des restaurateurs du Québec.

46. Winson A (2004) Bringing political economy into the debate on the obesity epidemic. Agric Human Values 21, 299-312.

47. Miedema JM (2006) A Study of Redundant Trade in Waterloo Region version 7. Report no. 222492. Waterloo: Region of Waterloo Public Health.

48. Wechsler H, Basch CE, Zybert P, Lantigua R \& Shea S (1995) The availability of low-fat milk in an inner-city Latino community: implications for nutrition education. $\mathrm{Am} \mathrm{J}$ Public Health 85, 1690-1692.

49. Kaufman PR (1999) Rural poor have less access to supermarkets, large grocery stores. Rural Dev Perspect 13, 19-26.

50. Morris PM, Neuhauser L \& Campbell C (1992) Food security in rural America: a study of the availability and costs of food. J Nutr Educ 24, Suppl., 52S-58S.

51. Dunnet CW (1980) Pairwise multiple comparisons in the unequal variance case. J Am Stat Assoc 74, 372.

52. Dugas C (2000) L'espace rural québécois. In Gouvernance et territoires ruraux, pp. 13-40. Ste-Foy: PUQ.
53. Connell CL, Yadrick MK, Simpson P, Gossett J, McGee BB \& Bogle ML (2007) Food supply adequacy in the lower Mississippi Delta. J Nutr Educ Behav 39, 77-83.

54. Eisenhauer E (2001) In poor health: supermarket redlining and urban nutrition. Geojournal 53, 125-133.

55. Llewelyn C (1997) Food Shopping in Rural Wales. Cardiff: Welsh Consumer Council.

56. Horowitz CR, Colson KA, Hebert PL \& Lancaster K (2004) Barriers to buying healthy for people with diabetes: evidence of environmental disparities. Am J Public Health 94, 1549-1554.

57. Bodor JN, Rose D, Farley TA, Swalm C \& Scott SK (2007) Neighbourhood fruit and vegetable availability and consumption: the role of small food stores in an urban environment. Public Health Nutr 11, 413-420.

58. Toronto Food Policy Council (1996) Food Retail Access and Food Security for Toronto's Low-income Citizens. Discussion Paper no. 7. Toronto: Toronto Food Policy Council.

59. Winson A (1993) The Intimate Commodity: Food and the Development of the Agro-industrial Complex in Canada. Toronto: Garamond Press.

60. Sone M, Aguda N, Malaviya N \& Mercer J (2001) Hungry for Change: Accessibility to Affordable, Nutritious and Culturally Appropriate Food in The City of Toronto. Report no. PLA 1106. Toronto: University of Toronto.

61. Cheadle A, Psaty BM, Curry S, Wagner E, Diehr P, Koepsell T \& Kristal A (1993) Can measures of the grocery store environment be used to track community-level dietary changes? Prev Med 22, 361-372.

62. Green L \& Kreuter M (1991) Health Promotion Planning: An Educational and Environmental Approach. New York/ Toronto: McGraw-Hill

63. O'Neill M, Dupéré S, Pederson A \& Rootman I (2006) Promotion de la santé au Canada et au Québec, perspectives critiques. Lévis: Les Presses de l'Université Laval.

64. Sloane DC, Diamant AL, Lewis LB, Yancey AK, Flynn G, Nascimento LM, McCarthy WJ, Guinyard JJ \& Cousineau MR; REACH Coalition of the African American Building a Legacy of Health Project (2003) Improving the nutritional resource environment for healthy living through community-based participatory research. J Gen Intern Med 18, 568-574.

65. Carey E (2005) Thirsting for health. Toronto Star, 30 May. http://www.torontoalliance.ca/urban_challenges/ community_services/articles.asp?articleID $=293$ (accessed December 2007)

66. Marquis M \& Simard S (2004) Bottin statistique de l'alimentation. Report no. 2-550-42974-5. Québec: Ministère de l'Agriculture, des Pêcheries et de l'Alimentation. 